\title{
FEAR IN RELIGION*
}

\section{El miedo en la religión}

\section{0 medo na religião}

Bhawani Shankar Adhikari

bhawanishankar.adhikari12@gmail.com

Fecha de recepción: 12 de diciembre de 2019 Fecha de aceptación: 18 de marzo de 2020

\begin{abstract}
Fear in religion deals with the common fear of those people who convert their creeds from one religion to another. It is too complicated to adjust in the same society and with the same colleagues where they used to live before. It has been discussed religion with war, politics and humanism respectively. It has displayed how to apply fear positively in all of the aforementioned ideas of religion with other ideology for the solution of all kinds of the misfortune and problems. Positive fear is meaningful and negative fear is harmful in life. All these concepts are linked with the fear of religion. It draws even the concept of remaining in the same religion rather than changing it as we change the dress. Religion is a social identity and it naturally becomes complicated and enters the fear in the psychological zone in the society when we convert ourselves from one religion to another.
\end{abstract}

\section{KEY WORDS}

Dimensions; Poisonous; Positive Fears; Negative Fears; Rebuke; Hindu; Muslim; Christian; Politics; Jews.

\footnotetext{
*English lecturer, Balmeeki Campus, Kathmandu Nepal Sanskrit University, Nepal
} 


\section{RESUMEN}

El miedo en la religión se funde con el previsible miedo que sienten aquellas personas que convierten sus credos de una religión a otra. Es demasiado complicado encajar en la misma sociedad, con los mismos colegas donde antes vivíamos. La religión ha sido discutida junto con la guerra, la política, y el humanismo respectivamente, ha mostrado cómo aplicar el miedo de manera positiva en las ideas de las religiones anteriormente mencionadas junto con otras ideologías para poder resolver todo tipo de infortunios y problemas. El miedo positivo tiene un sentido y el negativo es dañino para la vida. Todos estos conceptos están ligados al miedo en la religión. Nos enseña incluso el concepto de permanecer en la misma religión en lugar de cambiarla como hacemos con la vestimenta. La religión es una identidad social y naturalmente se torna en una complicación y deja lugar al temor en el área de la psicología de la sociedad cuando nos convertimos de una religión a otra.

\section{PALABRAS CLAVE}

Dimensiones; tóxico; miedo positivo; miedo negativo; reprimenda; hindú; musulmán; cristiano; políticos; judíos.

\section{RESUMO}

0 medo na religião lida com o medo comum das pessoas que convertem seus credos de uma religião para outra. É muito complicado se ajustar na mesma sociedade e com os mesmos colegas onde eles moravam antes. Foi discutido religião com guerra, política e humanismo, respectivamente. Ele demonstrou aplicar positivamente o medo em todas as idéias de religião acima mencionadas com outra ideologia para a solução de todos os tipos de infortúnios e problemas. 0 medo positivo é significativo e o medo negativo é prejudicial na vida. Todos esses conceitos estão ligados ao medo da religião. Ele desenha até o conceito de permanecer na mesma religião, em vez de mudá-la à medida que mudamos o vestido. A religião é uma identidade social e naturalmente se torna complicada e entra no medo na zona psicológica da sociedade quando nos convertemos de uma religião para outra.

\section{PALAVRAS-CHAVES}

Dimensões; tóxico; medo positivo; medo negativo; repreensão Hindu; muçulmano cristão políticos; Judeus.

\section{FEAR'S INTRODUCTION}

Fear has multiple dimensions. Various types of fears in different fields do have the various forms. The cultural fear is different from that of social fear, political fear and the fear of superstition. The fear of wild animal differs from the attack of domestic animals' fear. Fear of cobra's attack differs from other types of serpents because cobra is such a poisonous that the animals and human beings cannot survive more than a few hours of its attack. Fear of tigers' and bears' attack cannot be measured and compared with the fear of other animals' attack. Fear of bomb attack, chemical attack, missile attack, attack of guns and bullets is greater than other attacks as a whole since such attacks are the source of destruction and death. These different kinds of the fears can be categorized in the form of the positive and negative fears. The negative form of fear does not bring any solution of the problems and it rather leads the problems in the worst condition. The negative fear must be addressed on time. In contrast, positive fear draws the positive concept and brings the solution of any kinds of the problems in day to day life. But fear is a creative consciousness and it is beautiful because it brings the solution of the burning issues of the scarcity for the humanity in the globe.

\section{RELIGIOUS FEAR}

Among other kinds of fear, religious fear is the most powerful and strongest one. Fear of religion is deeply rooted in the heart of the people. The religious faith is unshakable and ineradicable from the heart of the people. People can change their political faith and the connection in party politics from one party to another one. People do not fear to change their political party for the sake of personal benefit. They do not fear to convict the political belief and to go another party but when they have to change their religion, and then they need to think in it. They do have the greater fear in god and they cannot do it so easily. The same stone trodden many times cannot be kicked again once the stone is erected in the form of god and offered with sweets and flowers. It happens because of 
the fear that comes in he minds of the people. The person may become furious and rebuke the god of stone but when the same person happens to be in the temples, he/she cannot do so because he/ she does have the fear of the gods. The fear of the almighty god is stronger than the fear of anything else to bring people in the form of the proper manner and the disciplined life style.

Religious faith comes out from the heart of the people automatically. Religion is not imposed but it must flow from the heart of the people just like the flowing of the river. Rabindranath Tagore's play "Malini" draws the two characters, Supriya and Kemankar who debate in a dialogue from regarding the belief in god. Supriya advises Kemankar that god is not found in the heart of the living world of men. Tagore speaks about the concept of god mainly through the mouth of his character, Supriya in the following lines:

Your hope of heaven is false; Kemankar. Vainty have I wandered in the wilderness of doctrines, - I never found peace. The god who belongs to the multitude and the god of the books are not my own god. These never answered my questions and never consoled me. But, at last, I have found the divine breathing and alive in the living world of men. (136)

This extract indicates that gods are not found in the religious books and in wandering. The concept of peace is not possible to gain the God in wanderings in the wilderness of doctrines. The gods of books cannot console the person and neither can answer the questions of anyone by the gods of the books. The divine breathing and the living voice of god is found in the living world of men.

Religious faith comes with the help of education and understanding too. It is also the matter of environment and upbringing. Rabindranath presents the example of it in his play "Malini" in which the main actress Malini was born in the palace of Hindu king and she got the education with the Buddhist monks and she found that Buddhism was better than Hindu religion.

It is not all levels of people who cannot change their religious faith but it is the middle class people and high class people, who are afraid of the social norms and values, cannot convert themselves in other religion from the existing one. Once the people change the religion, there comes the unimaginable change in the social belief and the life style. Those people who have the religious moral values and dignity do feel odd to change their creeds and to behave in the social life. If a Hindu becomes a Christian, then he/she has to avoid the cultural and social values of Hindu religion. $\mathrm{He} / \mathrm{she}$ has to quit to celebrate the Hindu festivals and it becomes obviously too complicated to him/her to adjust in the society. He/she feels something lacking in him in the society. He/ she feels that the society does have the different perspective to judge him from the previous one. $\mathrm{He}$ /she finds unnatural himself/ herself in the eyes of the people. So a person thinks many times before he/she becomes a Christian and vice versa. These types of people do have the fear of not only the god but also the fear of the society to change themselves from one religion to other one. People do not want to lose their social identity and the dignity that they have gained in life. So people are scared of converting their creeds to save their social identity.

It is the level that helps and determines people to change them from one religion to another one. Some people have to change their religion by the situation and the condition of life. When a person is working illegally in another country, then he/ she gets the support from the church and it does not make any difference and difficulty to become Hindu or Muslim a Christian for the protection of life in danger. Once he/she becomes a Christian in such a condition, then it becomes easy to deal with the society where he/she lives and it becomes a kind of habit and feels easy when she/he comes back to his/her own society too.

To change religion in the under developing nations is easier than the other advanced nations. When people do not find any alternative to survive in poverty and if they get a bit economic support from the Christianity, then they naturally change their religious faith from Hindu and Muslim into Christian one. It is the need of them to survive in life. It does not become complication to them to deal in the society and the society also takes it normally. The marginalized and so called untouchable caste people do not have the respect in Hindu religion and when they become Christian, it becomes a matter of pride and dignity to them in the society. They do not only get the economic support but also the respect in Christianity. If so, why should not they become the Christians? In fact, it is the situation that compels them to 
become Christians. It is a human nature to seek love and respect and the individual identity in the society. The main cause of making them Christian is the existing discriminating social structures. The society differentiates people as touchable and untouchable. So the untouchable people of the society tend to convert their religion into Christianity in which the concept of touchable and untouchable is not found. In this sense, they feel proud of themselves to be the cook of those who made them untouchable in their society.

Those people who have their high ambition do not feel odd to change their religion. Religion is often related with politics and it is through the religion the leaders become successful and powerful. The India Prime Minister - Damodar Modhi is the example of leader of Hindu people. He has got the strong support of Hindu. The Hindu dogmatists cannot even be thought to change in their creeds and they are always in need of their Hindu political leader and no other means and money can shake the foundation of such Hindus. Not only other religion but even Christianity fails to affect the politics of such religious leaders. So religious politics is much more powerful and fearful in the world politics than other kinds of politics because such politics can invite the religious civil wars in the country. Other religion having people may not get justice if the religious leader keeps the negative eyes to them.

Politics in religion is much more dangerous and harmful for the nations where various religions are in practice. The concept of peace and harmony becomes too difficult to maintain. The leaders of the under developing countries do feel easy to do the religious politics to come in the power. They misuse the religion and they feel easy to change their religion from Hindu to Christian and vise versa. They become Christian in disguise form and they take huge sum from Christianity and work for them. They even become the agent of converting the religion of the people. The Christians also feel easy to spread the Christianity and to do the religious politics indirectly. In fact, Christians trust such leaders and invest the huge amount to such leaders because they feel comfortable to complete their missions through the mechanism of the political party of the country. In such cases, other religious people do have the fear of the existence of their own religion and they protest against such Christians politics. As a result, it can violate the existing religious and social harmony of the nation. So, it is necessary to prevent such possible disaster in the nation.

\section{RELIGION AND WAR}

These two terms- religion and war- are interconnected and inter-related. Religion has become the root cause of inviting the most devastating war throughout the globe. The fear of war is always lurking within the heart of religion but it is invisible until and unless the war takes place. Some of the wars caused by the religion can be confined within the social and cultural forms. Such wars violate the social peace and harmony. The fear of such discomfort zones cannot be seen but only felt and realized in the hearts of the individuals in the society in such cases.

Taslima Naslin's novel "Lajja" is the example of reflecting the darker side of the religion. It shows the conflict between Hindus and Muslims in Bangladesh.

When Hindus were maltreated in Bangladesh, the country turned a blind eye to the sufferings of a part of its citizens simply because they followed a different religion from that of the majority Muslim community. Thus, Islam is the major factor in deciding the thoughts and behavior of its followers in Bangladesh. Hence, association with a few basic principles of Islam is necessary to size up the situations and events in the writings of the Taslima Nasreen, events in her personal life and the lives of her characters potrayed in her writings. Such intimacy is also important because Taslima Nasreen's fight for the cause of women becomes a fight against the darker side of her religion, rather a total rejection of religion (Raut P.I)

Religious fundamentalism is the main cause of conflict and war in the society. Religion has got its darker side and the majority of the religious community makes the decision over the minority. In Bangladesh, Hindus were in the minority and they were not only maltreated but even killed by the Muslim community. Taslima Nasleen has expressed her view in a interview with Karan Thapar "we should not practice any religion because it is against humanity, against Hinduism, against human rights, against women rights, against right of expression ( Raut P.I)". Her interview reveals that religion is against of all the human values and norms if we practice it in day to day life in society. It draws the picture of 
war between Hindus and Muslim in Bangladesh. It is an inhuman human picture experienced and realized by Hindus dwelling in Bangladesh in minority in Muslim community.

The golf nations are not free from the war of religions. Afghanistan has become the victim of religious war in the name of Taliwan- which is the war in between Shea and Sunni two different sects of Muslim religion.

Whatever types of war took place through out the globe was based on the religion. Soft information about it goes:

A religious war or holy war (Latin: bellum sacrum) is a war primarily caused or justified by differences in religion. In the modern period, debates are common over the extent to which religious, economic or ethnic aspects of a conflict predominate in a given war. According to the Encyclopedia of wars, out of all 1,763 known/ recorded historical conflicts, 123 , or $6.98 \%$, had religion as their primary cause. Mattew White's The Great Big Book of Horrible Things gives religion as the cause of 13 of the world's 100 deadliest atrocities. In several conflicts including the IsraeliPalestinian conflict, the Syrian Civil war, and the wars in Afghanistan and Iraq, religious elements are overtly present but variously described as fundamentalism or religious extremismdepending upon the observer's sympathies. However, studies on these cases often conclude that ethnic animosities drive much of the conflicts (Wikipedia).

It shows that no war can be imagined in the absence of the religion. So, religion is a very sensitive one and we must be aware of handling the religion to avoid the wars. If we fail to deal with religion, it causes the disaster to the whole humanity.

\section{RELIGION AND POLITICS}

The politicians know how to take the votes of the public of different religious community. When the politicians go in Muslim community, they put on the caps and other Muslim's clothes and appear in the program to attract the public and to gain the sentiment of them towards them. It is often seen and felt in the election time mainly in the under developing nations like Nepal and the advanced nations like USA, UK and other European nations too bring the special programs targeting to different religious people to gain the vote. The present Indian prime minister, Narendra Modi has won the election for two terms with the support of Hindu voters and even by the promise of doing better support to the Muslims and gaining the Muslims' votes directly or indirectly.

Politics and religion can not be isolated in practical field. The relationship between politics and religion is well expressed:

Religion and politics, though conceptually distinct entities, do indeed intersect in all manner of ways. In practice, religion cannot keep itself aloof from politics. The intermingling of religion and politics is permissible as long as it facilitates meet the objectives of securing a dignified life for all preventing discrimination on the basis of religion, checking religious bigotry, and managing frenzied inter-religious and inter-communal conflicts that threaten to plunge societies into barbarism. But if the intersection of religion and politics fails in fulfilling these aims, then their amalgamation must be restricted. Religious groups participate in a wide variety of political activities which sometimes causes the breaching of peace and harmony in the society. The same is true with Bangladesh and the evidence of which is truthfully mirrored in Taslima Nasrin's Lajja . . . . The book deals with various historical events since 1947 and reveals the cruel aspect of intersection of religion and politics in the persecution of Hindus, a religious minority on Bangladesh, by the Muslims, who were in the majority. (Kumari 1-2)

Religion and politics go side by side and it becomes sound until and unless one harms the other. Religion and politics must go simultaneously to fulfill the goal but when the intersection of religion and politics fails in achieving the goal, and then it must be restricted to go together. Religion's function in politics tends to be detrimental to the minority from the majority of the groups as it has become so to the minority Hindus from the majority of Muslims in Bangladesh in 1947.

Adolf Hitler's politics moved around the Jews religion. The aim of Hitler was to exterminate the Jews from the world. Hitler's politics is to give priority to the Aryan people and to chase away the Jews from Europe. Hitler thinks that the development cannot become possible with the Jews. "A development began which has always 
been the same or similar wherever and whenever Jews came into contact with Aryan peoples (Hitler 279)". Hitler believes that development remains always same with the existence of the Jews. So, the Jews are to be either exterminated or chased away from Germany. Hitler writes about the Jews and their characters:

As soon as the first permanent settlements had been established the Jew was suddenly 'there'. He arrived as a merchant and in the beginning did not trouble to disguise his nationality. He still remained openly a Jew, partly it may be because he knew too little about the language ... slowly but steadily he began to take part in the economic life around him; not as a producer; however, but only as a middleman. His commercial cunning, acquired through thousands of years of negotiation, as an intermediary, made him superior in this field to the Aryans, ... commerce seemed destined to become a Jewish monopoly. The Jew began by lending out money. (Hitler 279-280)

Jews were business minded people; they knew how to do the trade perfectly. Jews became the source of fear to Hitler and he wanted them to clear out from Germany. Perhaps Hitler was afraid of Jews in his politics and he intended to be free from their monopoly in politics as they had the monopoly in economics and trade in the society. Hitler's tone of fear is in these lines as he writes "Thus, he gradually came to form a state within a state. He came to look upon the commercial domain and all money transactions as a privilege belonging exclusively to himself (Hitler 280)". Hitler did not want the Jews in the power of trade. Politics is in fear with Jews like religion and vice versa. Hitler has called the Jews as leech, parasite, liars, cheat, merchants, mask, unchanged in inner nature etc and it is called the conflict between the politicians and the religion. "His inner nature is not modified there by (Hitler 283)". It is a criticism to religious people by the politician.

\section{RELIGION AND HUMANISM}

Religion is to serve the humans. It is to make the life easier and comfortable to lead ahead. It is to make human life worthy. It teaches people to become kind, generous, co-operative and ready to help others at the time of its need. Religion is to inculcate the culture, and customs in life. It is to transform the life in a proper and easier path from the complicated and complex forms of the day to day affairs. It is the process of becoming disciplined and cultured one in the practical field of life. Religion is a kind of ornament of life and it is the process of making human life peaceful and the harmonious one. It is the method of killing all the anxieties and unnecessary worries of life. Religion is the rule of life. It is the positive aspect of life. So, religion is linked with the ideas of humanism.

If religion provides the principle of leading the life in a disciplined form, humanism gives the concept of having positive and supportive feelings to others. But humanism is an abstract term and very complex to define." .... Humanism is a word with a very complex history and an unusually wide range of possible meanings (Davies 2)". The concept of humanism comes not with the definition but with the action of humans in society. The meaning of humanism becomes clear in its contexts. "Life would certainly be much easier (Davies 2)" with the concept of humanism no one feels frustrated and fed up of life if there are humanistic principles applied in the daily affairs of life of the individuals in society.

The principle of humanism is not confined with society but it is concerned with scientific inventions and discoveries to make the life more comfortable and easier than what it was before and what it is now. "Another kind of "humanism", a secular rationalism and scientific positivism that drew sustenance from the work of scientist (Davies 3)". All the scientific discoveries to make the day to day life easier are the examples of the humanistic activities. So, humanism is concerned with the total well- being of the human life. The function of humanism and religion is the same one since the target of both is to serve the people.

Man is a talking animal and man must have the rights of freedom of expression and the dignity of being to survive as human in society. "To be radical is to grasp things by the root. But for man the root is man himself (qtd Davies 8)". The idea of Karl Marx is quoted by Davies to define the idea of humanism. "The root of man is man himself" means man has to become co-operative to other man to create the humanistic principle in society. In other words "rationality" is the principle of humanism.

The term religion of humanity is feeling of "love" to one another in social life. "The phrase 
religion of humanity was coined by Thomas Paine (Davies 26)". The principle of religion of humanity refers to the idea that man must behave as a god to himself. "Man is god to man or god is nothing other than man to himself (Davies 28)". It shows that man is no different from god. When there is due respect and love among men, then it is called humanism. The religion too must not forget to give due respect to the man. When man finds the God in man and then only the man respects man. In fact humanism is a kind of religion and the satisfaction must come through the service of the man rather than in the service of the God made out of the stone.

Anti-humanism is the principle in which love and respect is not found. It is the feeling of animosity. Anti-humanism is the process of end of humanism. In the end of humanism, people have only the words of humanism in their mouth but the actions are against of what they say. In this context, Edward Abbey's idea is quoted "I am a humanist; I'd rather kill a man than a snake (Davies 25)". This quotation clarifies the concept of humanism and the end of humanism. But religion attempts to save the life of man and kill the snake. So, religion must be combined with the principle of humanism. But people are not free from the fear of end of humanism. When religion does not function as a pure form of religion, then it turns out to be the end of humanism in the world.

In short humanism works for human's comfort. It is "a system of thought criticized as being centered on the notion of the rational, autonomous self and ignoring the conditioned nature of the individual (Google)". It indicates the social co-operative activities other than the individual task. Religion and humanism must have the positive perspective to serve the humanity in a disciplined form but the fear always lurks behind the minds of the individuals. The positive fear always leads to the positive and creative aspect of life. Positive fear is the only one method of making life meaningful as Desh Subba has mentioned. "Fearism has a positive perspective (Subba 332)". Fear of religion, fear of war and fear of politics must be positive fear and the positive fear makes the solution of all the problems of the globe.

\section{CONCLUSION}

Fear has got both positive and negative perspective. Fear was defined in a negative form in the past but now fear is taken in a positive perspective. Fear in religion is the fear of getting adjusted in society in day to day life. The person who changes the religion feels strange in the same society and the colleagues where he or she used to live before. The person who changes his religion from one religious belief to another religion naturally finds him different from other people.

Religious belief must come from the soul of the person. The artificial form of changing the religion is not good but if it is converted from the souls and hearts of the people, then they do not feel odd even in the same society where they used to live before.

Religion is the root cause of the wars, conflicts, disorder, murder and disharmony in the society. But if the fear of war is realized from all levels of people positively, then the war does not take anywhere.

Religion and politics go side by side and the minority groups of people get maltreated by the majority groups. As a result, murder and conflicts take place but the positive fear can avoid the misfortune and maltreatment in the society. Religion must have good relationship with the principle of humanism. If the positive fear functions in the religion and humanism, then it becomes the source of solution of all kinds of the problems of the globe. 


\section{WORKS CITED}

- Davies, Tony. Humanism. Routledge, London and New Yorkl. 1997. Print.

- Hitler, Adolf. Mein Kampf. Adarsha Books: New Delhi, India. 2002. Print.

- www.google.com. https://en.m.wikipedia. org

- kumari, Dr Archana. Intersection of Religion and Politics in the Persecution of Minorities in Taslima

- Nasreen's Lajja. Department of English and Foreign Languages, Guru Ghasidas Vishwavidyalaya: A Central University,
India. https://www.google.com .Pdf.

- Raut, Kaustubh. K. Religious Fundamentalism in Talslima Nasreen's Lajja: A Critical Analysis. Department of English, Gondwana University, Gadchiroli, India. https://www.google.com . Pdf.

- Subba, Desh. Philosophy of Fearism. Xlibris. 2014. Print.

- Tagore, Rabindranath. "Malini". The Magic of Words. M.K Publisher and Distributers: Bhotahity, Kathmandu, Nepal. 2000. Print. 